\title{
Locating the Choreomusical: The Case of European and American Dance Fiddling
}

\author{
Colin Quigley
}

\section{DOI: 10.21104/CL.2016.4.01}

\begin{abstract}
This essay takes the term choreomusical as a starting place for discussion of attention to the study of music and dance relationships within ethnomusicology and ethnochoreology. Extending this neologism, choreomusicology has been proposed as a distinct disciplinary perspective on its own. Recent publications advocating for the usefulness of this joint research perspective have begun to establish this terminology more generally. Explicit studies of music-dance as a unitary phenomenon in performance, however, long predate this development, particularly in the closely connected fields of ethnomusicology and ethnochoreology. This history is here acknowledged, tracing interest in this research topic to major founding figures in both disciplines, as they took shape in the 1950s. An examination of the application of the choreomusical perspective to the case of European and American dance fiddling provides examples of how such inquiry has been carried out and identifies emergent methods which make use of advances in digitally based sound and movement analysis. A more nuanced usage of the terms is advocated.
\end{abstract}

Keywords choreomusicology, ethnomusicology, ethnochoreology, Fiddle, Step dance.

Contact Colin Quigley, PhD., Senior Lecturer and Course Director Ethnomusicology, University of Limerick, Irish World Academy of Music and Dance, Limerick, Ireland; e-mail Colin.Quiqley@ul.ie.

Jak citovat/How the cite Quigley, Colin. (2016). Locating the Choreomusical: The Case of European and American Dance Fiddling. Český lid 103, 515-536. doi:http:// dx.doi.org/10.21104/CL.2016.4.01 
In "Musical Feet and Dancing Bows," a keynote address to the North Atlantic Fiddle Convention (NAFCo) conference of 2006, I asserted that "all too often sound and movement, dance and music, musician and dancer are separated when ethnomusicologists, ethnochoreologists, and researchers from related fields, proceed to examine the two activities apart from one another" (Quigley 2006). There are reasons for this, of course. Within academia, knowledge is partitioned by discipline and department and specialised terminology, analytical tools, and topics of interest develop within their walls. But in practice throughout Europe both east and west, around the North Atlantic rim, and across North America in the many idioms that characterise the wide-spread shared use of fiddle to accompany vernacular traditional dance they come together to energise and animate performance in intimate relation. Study of one can throw light on the other and study of the whole of the music-dance performance provides insight into the nature of a core aesthetic experience that contributes much to the vitality of such music-dance idioms as well as distinguishing among them.

How to best refer to the shared domain within which music and dance come together to interact with one another, as well as what to call the complex whole constituting their joint performance, presents a problem. I long resorted to the music-dance conjunction used above; "dance music" having another quite specific meaning in everyday usage. "Choreomusical" is increasingly found in dance and music scholarship as a felicitous term to label investigations that encompass the joint phenomenon of musicking and dancing as a unitary form of performance and cultural expression; while, "choreomusicology" is proposed as a discipline in itself. In the following essay, I aim to parse the term more finely, perhaps sharpening its analytical application, while continuing to take advantage of its convenience, in relation to a particular context of music-dance joint performance, the dance fiddling of Europe and North America.

\section{Choreomusicology}

Recognition of the significance of music-and-dance/dance-and-music relationships has been present in the fields of ethnomusicology and ethnochoreology (or dance ethnology as so-called in North America), since their disciplinary articulation in the 1950s and 60s. Earlier instances of such could no doubt be found in the broader literature of musicology and dance studies that preceded this watershed period. Explicit investigation of these interrelations is likewise to be found in both, admittedly closely aligned fields, but seems to have been prompted primarily from the choreological enterprise. Joann Keali'inohomku, for example, discussed Gertrude Kurath's conviction about the interconnections of dance and music in a retrospective essay (Keali'inohomoku 1995). This North American pioneer and founder of ethnochoreology argued powerfully for 
recognition of 'Dance-Music Interdependence' as a reason for their joint analysis in a 1957 essay in Ethnomusicology (Kurath 1957); and, she cites Willard Rhodes' 1956 assertion that music is "a physical response to a motor impulse" making dance "inseparable from music except for purposes of study" (Rhodes 1956: 4). Therein lies the rub of course, as he goes on to acknowledge that,

Choreology is a distinct discipline in its own right and ethnomusicology has no intention to poach on its territory. However, the inter-relatedness of dance and music makes it imperative that the ethno-musicologist take greater cognizance of the dance. Few ethnomusicologists are equipped to deal adequately with the dance, and few students of the dance are qualified to deal with analysis of the music, but there can be the kind of collaboration that George Herzog contributed to Bessie and May G. Evans' American Indian Dance Steps (1931). By recording in dance notation dances in relation to the musical notation of their accompanying songs Gertrude Kurath has pioneered in this fertile field and proved herself one of the few persons qualified to work in the two disciplines. Her 'An Analysis of the Iroquois Eagle Dance and Songs' (1953) is a monograph that might serve as a model for future studies of this type. (Rhodes 1956: 4)

Keali'inohomoku herself made an early contribution to this topic in "Dance and Self-Accompaniment" published in the journal Ethnomusicology in 1965. In a 1974 paper presented at the joint conference of the Congress on Research in Dance (CORD) with the Society for Ethnomusicology (SEM) that she shared with me, "Dance is Music in Four Dimensions," Joann argued for the visual study of music. "Truly," she writes, "the ethnomusicologist and the ethnochoreologist have the same phenomenon as their center of attention." Wherever performers may fall along a spectrum from "silent dance-maker, through the sound-making dancer, through the musical-sound make" all are "tied by their common manipulation of time" (Keali'inohomku 1974). Work by pioneering European ethnochoreologists of the same era includes that of Hoerburger (1956; 1960), Katzarova (1960), and Martin (1964). In these latter studies the focus is on relationships between music and dance structures, a perspective that informed the work of the International Council for Traditional Music (ICTM) Study Group on Ethnochoreology before 1988; it was the topic of its meeting in 1976 in Zaborów (Poland) represented in Dąbrowska and Petermann (1983) and is a level of choreomusical analysis that continues innovatively in the work of Rakočević (2007). In a cultural context in which music and dance are conceptually separable but, at least in vernacular idioms, almost always found together, this is a natural point of entry into choreomusical phenomena.

Attention by ethnomusicologists to "dance, movement, and gesture", as the title of the current Society for Ethnomusicology Section has it, is now 
well established and is a strong strand within the discipline; awarding of the Merriam Prize for best monography to Sensational Knowledge demonstrates this well (Hahn 2007). Attention to "the body", has, as across the humanities, become, if not commonplace, nevertheless common and along with it movement analysis has become a more common technique in its methodology, while the collaboration advocated so long ago by Rhodes, continues as well (Eriksson and Nilsson 2010; Dick 2016).

The scope of this area of inquiry and just how to name it has varied over time and context of application, but at least since the mid-1990s the term choreomusical seems to have emerged as the most felicitous term being used to characterize investigations that encompass the joint phenomenon of musicking and dancing as a unitary performance. The publication of Choreomusical Perspectives on Maritime Southeast Asian Performing Arts would appear to establish the term within the ethnomusicological and ethnochoreological mainstream (Mohd Anis Md Nor and Stepputat 2017). This is not a surprising context in which to find the choreomusical apt in its application, as "performing arts in most parts of Maritime Southeast Asia are seen as an entity where music and dance, sound and movement, acoustic and tactile elements intermingle and complement one another." The editors cite their general aim herein "to suggest an alternative" to the continuing scholarly and academic separation of music and dance study, heralding "choreomusicology" as a new "holistic field of study that combines the study of music and dance, and puts the relationship itself into the focus of research" (Mohd Anis Md Nor and Stepputat 2017: i, xv-Xvi). They place the recent surge of activity within this nascent discipline as emerging in the 1990s (and somewhat paradoxically, I would say) within studies of Western performing arts. Indeed, the term choreomusical is generally attributed to Paul Hodgins (1992), while Inger Damsholt (1999), Stephanie Jordan (2011), Paul Mason (2012) have become the most prolific voices for the specificity of a choreomusicological discipline within this cultural domain.

Explicit investigation of music-dance interaction in ethnomusicology and ethnochoreology as briefly reviewed above, however, long predates this work. The first occurrence of the term that I have yet found is in an identification of Garba as "a women's choreomusical form of mother-goddess worship celebrating fertility, performed as part of the Hindu autumnal harvest festival, Navratri" (Thompson - Yodh 1985). Thompson does not recall consciously coining the term (personal communication 19-11-2016); perhaps it is not so unlikely or distinctive a neologism. However, a full account of the term and, perhaps more importantly, its application, even within ethnomusicology and ethnochoreology alone, is beyond the scope of this essay. Rather, I focus now on how the choreomusical perspective has been explored within a vernacular western idiom, that of European and North American dance fiddling, providing a more detailed account of its applications. 


\section{European and North American Dance Fiddling}

Traditional fiddling and dance have a particularly close connection in European vernacular performance practice and its North American diffusions. From the time of Praetorius's description of the violin (1614-1620) this instrument rapidly penetrated all of Europe finding favor among all strata of society wherever there was already a native tradition of bowed-string playing (rebecs, fiddles, viols, bowed zithers, etc.). Among a variety of characteristics that might account for such a rapid spread and integration of the violin into vernacular dance music its volume and range of bowing techniques that offer a wide range of variation in attack and dynamics would seem well suited to articulating dance rhythms. Musicians adapted the new violins into local practice according to their musical needs producing a rich variety of hybridized forms. Throughout Central and Eastern Europe, it is most frequently found in small ensembles, including other members of this bowedstring instrumental family as well as a wide variety of instruments historically found in various regions and, more recently, most instruments developed or originating from the 19th century. In North-Western Europe, it is more often found as solo dance accompaniment. In North America, the violin arrived in large numbers during the 17th century. The immigrant European populations brought the instrument and its playing for popular dances of the era, extending and establishing its common use all around the North Atlantic. It became a site of significant Black-White musical exchange from the very early days of European settlement in the American southeast, where European instruments were played in European fashion in colonial houses by slaves of varied origin at the same time they were adapted among the Black slave in their own music and dance events. All along the southeast coast and among the interior mountains of Appalachia the fiddle was paired with the 5-string banjo, a North American instrument developed from West African origins and the distinctive rhythmic inflections of that region's fiddling became established. Indeed, all around the North Atlantic an area in which the basic musical (and dance) material and structures are widely shared, rhythm is probably the key distinguishing feature among the many regional styles that are now generally recognised (Quigley 2008c).

I first encountered and came to know the mutually-constructive generative fiddle and dance performance idiom as both fiddler and dancer within the context of North American Appalachian, Irish, and New England music revival scenes. I first investigated the phenomenon from a disciplinary perspective while working in Newfoundland, Canada, in the late-70s where I encountered vernacular traditional fiddling and percussive dancing that had not been regionalised or nationalised (Quigley 1985). This situation removed a certain degree of codification in its practice, thus drawing attention to the more spontaneous aspects of music/dance interaction in performance. 
Within such local vernacular settings, fiddling and dancing was practiced within families and among their immediate neighbours in homes, and later in small public halls. Each local community of dance and music practice became marked by the personalities of its participants. One such familial, neighbourhood, and local music/dance community with whom I became very well acquainted was that of the Benoits living in Black Duck Brook, on the Port-au-Port Peninsula on the west coast of Newfoundland. During my years of MA and PhD training and research from 1978-1987, I spent countless hours among them (Quigley1985; 1995). A description of one choreomusical moment, as caught on camera, can serve to convey the interconnectedness of an emergent performance. ${ }^{1}$

We are at home in the kitchen of Emile Benoit, the room in which locals come and go with great freedom of access, and in which the less intimate lives of the family and its neighbours are played out. Emile and his wife Rita, brother Joachim, son Wayne, and a few neighbours and other family members of the younger generation have gathered together for the filming of an interview to be used in a local television program production. Emile is asked to play and a typical music/dance performance takes place. Emile begins a wellknown tune [in a common and familiar rhythm]. Wayne is coaxed to dance. He and Emile find a common pulse, a shared groove as they perform together. Energised by the infectious rhythm and the good spirits of the room, "Uncle Joe" jumps to his feet and joins in the dancing, despite his advanced age and heavy-set body. The two dancers turn toward one another and converse for a moment in movement and sound. The others encourage them and after a moment all ends with their sounds and gestures of appreciation.

A closer review of the video recording allows a more detailed examination of how music and dance, sound and gesture intertwine to produce this performance. The strong and steady, down and up, motion of Emile's bowing arm, the back and forth of the bow across the strings, provides a powerful sense of propulsion to the music articulated in a steady flow of strongly accented beats in a straightforward duple simple meter. The so-called down-bow stroke is energetic and conveys what is locally called a feeling of "drive" that can be felt as well as heard by those in close proximity. Emile has become a rhythmic engine, heel and toe pounding out the same accented beat-pattern on the floor, the rest of his body accommodating and following these two movement impulses, the bowing and the stamping. All this happens in a moment. 
The group turns towards Wayne and urges him to dance. He rises from his chair, pauses a moment and begins to dance with a heavily weighted fullfooted step, followed by a controlled throwing of the free foot forward to strike the floor with the heel. A low hop is made on the supporting foot; the toe brushes the floor as the free leg swings back. Wayne then drops his weight onto that foot and continues the pattern in mirror image. The step pattern sounds each of the even four sub-divisions of the short musical phrase but accents them quite clearly: the thud of the drop, the strike of the heel, the lighter landing of the hop, the sharper tap of the toe, and finally a repeated thud to begin the cycle again.

This is Wayne's basic step, we may say. In it the strong first accent provides an impulse of energy that then flows though the body to be expended in the following motions, with a second impulse coming from the alternate whole-foot drop. The effect of this constantly repeating relation of foot to the floor extends through the body and produces a sustained down and up motion of the whole torso to which Wayne adds an up-down 'pumping' of his arms. For variety Wayne will occasionally omit the heel-stamp/toe-brush sounding free-leg gesture by lifting the foot clear of the floor and sustaining his weight on the supporting foot with a slight lift and back-slide that does not leave the floor, without producing much sound, thus punctuating the ongoing flow of the accented rhythm.

Wayne's dancing fits well with Emile's playing. The tune begins with an up-bow up-beat and then strong down-bow that is used at the start of each phrase of each strain of the tune. The first phrases of each strain are played with strong regular bow accents, the second with slurring patterns that cross the beat. And the melodic patterns of each strain and their sub-sections seem to flow from the impulse of the opening motif. Just as the energy of the dance is carried through Wayne's body as a reaction to the initial impulse, so Emile's melody is propelled by the accent pattern.

In the performance, we can see how Emile watches Wayne closely to establish and maintain the synchrony of pulsation in their shared groove. Compared to choreomusical idioms found elsewhere around the North Atlantic, this is not a complex pattern, which helps one to see, hear, and describe it in detail; but it remains no less powerful for that. The performance is full of energy, to such an extent that Joachim, not in the best of condition at 70 years of age, is inspired to join in the dancing. Of the older generation among whom the music/dance tradition was more actively practiced, it is not surprising that he performs somewhat more complex and more varied steps. But, the heavily accented pulsation remains as a foundation and the sound repertoire is the same. It is the gestural ornaments that become slightly more developed spatially for visual effect, without adding any different basic sounds to the music of the feet, albeit giving them a bit more nuanced variety. Joe finds the shared choreomusical groove as he watches Wayne and listens to Emile, but 
also as he sympathetically feels Emile and hears the sound of Wayne's dancing. He enters the performance with a kind of physical statement of 'here I am, dancing with you' to Wayne, by approaching him and even more strongly accenting his down beats by dropping any extra ornamentation. This produces a moment of maximum synchrony when their bodies are moving very much together even though their feet are doing different steps. After this climax the performance winds down as each participant returns the focus of attention to themselves.

The intimacy of family relations is mirrored in the tightly interwoven fabric of the performance. This was a context that I strove to enter by building my own competence as a means to understanding its dynamic. A short video from field tapes recorded at the time shows me working with Joachim. Looking at it in retrospect, I see and hear that I am playing one of Emile's compositions that features an irregular shortened phrase to which Joe easily adapts his dance steps. This idiosyncratic aspect of Emile's music is one to which other dancers accustomed to more regular tunes have some difficulty adapting in my experience. It is the musician's and dancer's shared knowledge of how to relate to the rhythm, the underlying pattern of its pulses, that holds the performance together. Feld and Keil offer the term "groove" to denote not the rhythm of the music (1994), but how the members of an ensemble share a way of relating to its accented pulse and it is useful here to identify the common generative pulse of the joint musicking and dancing performance.

Wherever fiddle music and percussive dance have been examined around the North Atlantic a similar mutuality of construction of groove in the music and dance is evident. Peter Cooke explores this phenomenon in some detail The Fiddle Tradition of the Shetland Isles (1986), using the analytical apparatus that dominates choreomusical investigation in the fiddle-dance domain. Native choreomusical terminology is elicited and interpreted; while its explication is sought through sound analysis and illustrated through transcription and notation of various kinds. Analysing musical and performance "style" he notes that,

The fiddle in Shetland was, above all, an instrument for dance.

... In dance music the prime ingredient is rhythm. ... Rhythm is all important to both fiddlers and dancers. The internal rhythm of a tune is contained both in its metrical duration patterns and its melodic accent. Such differences are enhanced by the best fiddlers and realized in varied movement and accentual gestures by the best dancers. (Cooke 1986: 97-98)

One fiddler emphasized the importance of the bow arm in producing the desired rhythmic effect: "Unless you can play the fiddle wi' a lilt in til [into] it, then there was no use even grapping a bow - it's the bowing and the lilt that [makes] you feel like dancing” (Cooke 1986: 98). 
"Lilt" is one of several vernacular terms used among Shetlanders to describe the quality of dance rhythm in the playing. The running notes of melodies in reels "are often notated as equal quavers, but in performance are rarely equal in duration". Variation in the infra-rhythmic structure of the tune, combined with variation in dynamic accents that make for good performances is achieved with the bow to produce playing that makes Shetlanders "feel like dancing". Cooke goes on to analyse the phenomenon of lilt by combining simplified notation of melody with sonographic representation of pitch graph and spectral envelope that clearly show a great variety in note length. "Lift" is another vernacular term related to the danceability of fiddle playing that is more related to tempo and accent, ie. rhythmic vitality, than it is to variation in note durations. As Cooke aptly notes, investigation of "these two concepts, 'lift' and 'lilt', proved a difficult task. They are affective qualities in the music and Shetlanders respond to their presence in shared feelings and in dance: there is little need to verbalise about two qualities that they all feel." (Cooke 1986: 98-100) The "electro mechanically produced melograph" notation, while useful in illustrating some aspects of style was not much help in many cases. "In the absence of more sophisticated techniques one has to fall back on aural perception, which appears to be no problem for the Shetlanders themselves." (ibid.: 116) Eliciting responses from fiddlers to particular recordings became a primary method for Cooke in this quest. Perhaps if he had been able to work in similar detail with the dancers some of the problems he encountered could be overcome; It is sure that a fuller understanding of these essential explicitly articulated choreomusical features of the Shetland fiddledance idiom would have emerged.

One can turn to an interestingly parallel, and more recent, study by ethnochoreologist Mats Melin for a view of the other side of the choreomusical coin (2015). Melin turns to a phenomenological approach to investigating the dancing of a not-too-far-removed fiddle-dance idiom, that found in Cape Breton, Nova Scotia, Canada. While Cooke, focussed on parameters of musical style, turns to his informants' "ears" and his admittedly limited ability to measure these parameters, Melin interrogates his proprioceptive perception of kinaesthetic experience while dancing. Proprioception, he explains, refers to "physically feeling one's own body in motion on an overarching but deep level, which integrates balance, flow, and fine and gross motor skills" (Melin 2015: 45).

He likewise finds vernacular terminology to identify key choreomusical characteristics of the Cape Breton fiddle-dance idiom. The relationship between a Cape Breton musician and dancer in performance, "comes down to the embodied knowledge of tempo, suitable tunes, bowing, and fingering, that, when applied, will provide the best conditions for a dancer to thrive and to perform. It is a symbiotic relationship that allows dancer and musician to feed off each other's energy in performance." "Drive" and once again 
"lift" are two significant terms in Cape Breton that prove difficult to define precisely. "When applied to music they are said to inject a surge of energy toward movement in general and dancing in particular. A fiddler applying lift and drive to the music makes you tap your feet as a listener, or makes you dance lighter and with increased energy. The two terms are part of the core components that bind the music ... to the dance in what is often referred to as 'old style' sound" (Melin 2015: 163). Herdman elaborates on how the two concepts inform and are manifest in old style fiddle technique (2010: 160167). She, in turn, quotes Heather Sparling, who writes, "the lift is hard to describe but one knows that it is happening by spontaneous audience applause and cheers, and by body language such as tapping or moving feet, erect bodies sitting forward in chairs, and smiles. I personally respond to lift physically, wanting to move and to dance” 2005: 291).

Melin takes the reader into such a choreomusical performance moment in a brilliant "personal ethnographic reflection on solo step dancing at a square dance" (ibid.: 246). Throughout this first person introspective, proprioceptively informed, account of his moment-by-moment experience as a dancer in performance, the music, its sounds, and its playing emerge repeatedly as key to the feeling of lift and drive.

All my senses are alert. I have become one with the hall and those around me. I straighten up. I feel the music flowing up from behind me on the stage. ... The level of alertness has increased gradually all through the evening and now it enables me to hear Kinnon's left foot beating out the rhythm in his characteristic way, a feature that adds to this culture's musical expression. He is creating a swing or, as the locals put it, he is really "driven'er!"... I can hear every note from the piano as well, adding to the rhythm of the tune. All sounds are layered, from primary and secondary music sounds to the background noise of the crowd as they converse and laugh.... With my mind's eye, I see Kinnon and Betty Lou [Beaton] playing and how they move as they do so. They do not sit still; their whole bodies work and move as they play. (Melin 2015: 247)

What he dances is determined from moment-to-moment.

A split second flagging in my mind suggests what would be [a good move] next. This is not always what gets performed, though. The music may tell me something different. Each musician provides his or her own take or variation on a tune, which, in turn triggers varied responses in movements that I "hear" in the music each time I dance. ... The music is coming to the end of a B turn. What will come next? Kinnon is an expert in combining excellent tunes together. The first 
notes of the next tune ring out; it is one of my many favorite Kinnon tunes ... and it has a melody structure that I feel brings out some of the best in my dancing. ... Kinnon's speed and timing is exactly right. Not too fast, but with that fantastic drive and ability to get the timing absolutely right for the dancer, to the fraction of a second. ... It is my own being and a connection with the musicians and their music creation that exist in the first instance. ... The music is "nourishing me," to use Melody Cameron's phrase. (Melin 2015: 248-249)

and so on. "The crucial connection between the music and how I dance is always prominent in my head" (Melin 2015: 249).

For insight into how the Cape Breton fiddler articulates the quality of "drive" and "lift" one can turn to Liz Doherty's Cape Breton Fiddle Companion (2015). "The use of the bow in Cape Breton fiddle tradition is fundamental in shaping aspects of the musical 'sound' such as articulation, accentuation and phrasing, thus generating the rhythmic 'lift' or 'drive' of the music" (Doherty 2015: 49). One key bowing technique used to achieve this emphasizes the initial beat of a phrase, providing impetus in the same manner that characterized Emile Benoit's playing, described previously. That region of Newfoundland, the Port-au-Port Pennisula, is not far removed from the northern tip of Cape Breton and is indisputably influenced by its music. The 'bow-push accent', that Doherty identifies, aims to

create a dynamic within a single note and, by applying this regularly throughout a tune, a sense of pulse is generated. This technique is applied to the primary accented tones of a measure. ... These typically happen on a down-bow and are further identified by the foot tapping pattern employed by the fiddler, marking the points where the main beat occurs. (Doherty 2015: 49)

Wherever we turn, all around the North Atlantic we encounter the same notion of a core choreomusical aesthetic that characterizes distinctive local and regional styles of music/dance. The series of publications resulting from conferences of the North Atlantic Fiddle Convention provides a rich sampling including the essays of Ballantyne (2012) and Shoupe $(2006,2008)$ addressing the larger frame of cultural constructions of dance and music, and the social roles ofdancer and musician. Sherry Johnson (2010) brings this broad conception of the choreomusical to ask why step dancers in the Ottawa Valley, Canada, continue to show an allegiance to traditional fiddling, while in other North American step dance regional idioms performing to popular music genres has become much more common. At the same time, throughout these essays, and more explicitly in others, the close connection of the shared experience of the beat, the rhythm, and the groove in the processes of musicking and dancing comes 
up repeatedly in relation to both fiddle and dance style. For example, "Why can't you dance to the piper?” (Ballantyne 2012), “The 'problem' with Scottish dance music: Two paradigms" (Shoupe 2008), and "The rhythmic dimension in fiddle-playing as the music moves to newer performing and learning contexts" (Cranitch 2008) all deal in one way or another with the consequences of removing this musical idiom from its close connection to dance. Extending our geographical region somewhat takes us to Jan Peter Blom's argument that in Scandinavia and other North Sea traditions, "significant regional differences in style pertaining to patterns of rhythm and bowing are apparent.... Such stylistic dissimilarities are reflection s of the music's functional relation to dintinct - and equally dissimilar - folk dance traditions within physically adjacent areas” (Blom 2006: 75). While Eriksson, Karen and Mats Nilsson (2010) in "Ethnomusichoreology? Ethnochoreomusic?" collaborate in an attempt "to link the research into music and dance with a view to discover whether this can be done, in what way it can be done and what types of questions then become interesting for further study". They focus on the metrical level to suggest that the dance beat and musical beat together constitute "the significant point of intersection in the encounter between dance and music" (Eriksson - Nilsson 2010: 260). Significantly however, they extend the notion of "beat" as "metre, movement and sound do not exist in a vacuum. ... The entire performance the making of music and dance - belong in ... a cultural context [in which] people's experience of and feelings for the dance and the music play an important role" (ibid.: 263-265). The real, experienced meeting "in the beat" becomes considerable more complicated than simply a matter of beat and metre (Nilsson 1995). While this review does not exhaust the many examples of attention to fiddle music and dance connections around the North Atlantic, the North Sea, and North America, it does illustrate a strongly shared recognition of their intimate relationship, among both the practitioners and the analysts, and suggest the ways in which the topic has been addressed.

Catherine Foley, writing about Irish sean-nos, or old-style, solo percussive dancing quotes her primary informant, as follows,

Sean nos dancing is what you think of the music; your own ideas. Dance embellishes the music. Dance adds to the music ... $A$ sean nos dancer picks out each individual note and puts in variations. ... Sean nos dance is not merely mirroring the rhythmic structure and phrasing of the music, sean nos dance enhances the music through a play of dynamics and syncopation where the music becomes an integral part of the dance and, in turn, the dance becomes an integral part of the music. (Foley 2008: 52)

Foley goes on to state that "this notion of embodying the music, interpreting the music, and enhancing the music percussively, sonically, and visually" are 
characteristics of what she calls "percussive dance forms in general" (2008: 53). This would not seem to be a controversial assertion. It is a more general point about sound and movement, music and dance relationships in this analytical category of dance practice, what Keali'inohomoku would have called soundproducing dance, itself perhaps a sub-set of "self-accompanied dance", in schema presented earlier. As in many instances where etic categories are applied, however, difficulties with generalizations are often encountered at their analytical boundaries. What are we to make of percussive dance without separate musical accompaniment? she asks. Foley argues that percussive dancers 'still perform to internalised and embodied music' (Foley 2008: 53). Most European based vernacular dance however, whether percussive or not, might be said to be in some internal aspect musical; or rather, as I wish to argue, choreomusical.

I agree with Foley that the choreomusical phenomenon of "meeting in the beat" is a more general one than the specific case of North Atlantic fiddledance idioms. It can be extended and demonstrated throughout the European and American fiddle-dance pairings. Foley points to the Hungarian men's percussive legényes dance genre, only one of a large range of so-called percussive dance genres found throughout the multi-ethnic population of the Carpathian Basin, which indeed is comparable to North Atlantic step dancing in the way its musicking and dancing interact and intersect. Accompanied in its traditional way by a string ensemble led by a violin player, the rich possibilities of bowed articulation of melody, in this case across the entire ensemble, are again closely aligned with the stamps, slaps, finger-snaps, and leg-gestures that typify this genre as well as the pair-turning dance suites typical of the region. Martin's seminal choreomusical study, previously mentioned, (1964) along with those of his Hungarian successors (see Felföldi 2001), well exemplifies the metrical and structural analysis that characterizes most of the classic European choreological research. Katzarova, for example, was likewise concerned with structural interrelations (1960), in particular with the phenomenon of non-congruent phrase lengths between the music and dance, which contrasts with the general regularity found throughout the rest of Europe.

The string-band accompanied dance traditions of the Carpathian Basin are a thoroughly studied body of material, albeit characterized by certain blindspots (Quigley 2008b), with which other aspects of European-American choreomusical investigation may be found illustrated in more recent work. I refer here to the sophisticated empirical analyses of music-sound production among the accompanying instruments and, in particular, their complex articulation of the unifying choreomusical beat, in Nilsson and Eriksson's sense, and its groove.

Particularly distinctive in this repertoire is a "smearing" of the pulse, a swelling and waning of the sound of the rhythmically accompanying instruments, folk versions of the viola and various sized contrabass. This key rhythmic effect (dancers will generally find their beat, in relation to these 
instruments), the parallel violin rhythmic production and, indeed, a complete examination of the players' techniques has been thoroughly investigated by Hungarian ethnomusicologists in some idioms (András 2009; Virágvolgyi - Felföldi 2000). The violin, though, remains the lead instrument, choosing melodies, setting both tempi and rhythm patterns as appropriate for dance genre and, indeed, the preferences of particular dancers. This leadership is accomplished through use of variation among the violinist's bow attack, speed, weight and so on, along with quite elaborate melodic ornamentation techniques; not to mention the key role of gestural, postural, and proxemical communication among ensemble members. Obviously, these kinds of analyses are only possible given a high level of competence in instrumental performance among the researchers that is supported by sophisticated audio recording and processing technologies and supplemented by visual analysis using film and video; thus fulfilling to a certain extent what Peter Cooke called for in 1986.

Linking this much more holistic analysis of musicking processes to a similarly sophisticated movement analysis remains a goal still only just being realized. The turn to techniques of proprioceptive awareness, as found in Melin's work, and supported by video-recording technology has offered one way forward. That approach has more in common with the phenomenological methodology and hermeneutic interpretive stance to be found in ethnomusicology and ethnochoreology as marked by the publication of the first edition of Shadows in the Field (Barz - Cooley 1997). In the context of studies that fall within the scope of this essay, one finds it in Timothy Rice's "Dialectic of Music and Dance in Bulgaria" which extends the earlier focus on metrical analysis to more generally discuss how the rhythmic structure of the music can be "read" on dancers' bodies (Rice 1995).

The tantalizing prospect of simultaneous sound and movement capture, data processing, analysis, and of course, at the last, interpretation is, however, finally dawning. The collaborative "tango-Music Danceability" project led by Stepputat is among the most advanced of efforts in this direction (Dick 2016). In a poster presentation accessible on-line, he explains and illustrates,

\section{Optical Motion Capture equipment tracks markers attached} to moving bodies. They are reconstructed in a $3 D$ environment based on a given body model. The level of detail is within a few miliseconds in time and milimeter in the kinematic domain. ... MIR [music information retrieval] provides several established procedures that allow for detailed analysis of music in different domains. One particular aspect of interest for the project is the rhythm and its execution in regard to micro-timing. (Dick 2016)

The Dance Studies and Music Technology team at the Department of Music, NTNU and The Norwegian Centre for Traditional Music and Dance is likewise 
working with simultaneous sound and motion capture; in this case in dance genres within the scope of the Euro-American fiddle-dance idiom I identify here (Mæland 2015). Not yet in publication, a report on this project made to the 29th Symposium of the ICTM Study Group on Ethnochoreology in Graz, Austria revealed differences in how the technologies are deployed, the mathematical techniques for processing the complex and massive amount of data that is generated, as well as the overall goals and interpretive frameworks. Other collaborative team projects with their own genre and technology specific idiosyncracies are, I am sure, not far behind. Simultaneous digital capture and computational analysis of music and dance relationships through such sound and movement analysis remains a new and developing methodology. Its advent may well help to account for the upsurge of interest in the choreomusical and the potential for this to develop into a distinctive choreomusicology in its own right. Yet, it will face the same intransigent analytical challenges and limits in application and usefulness as dogged the chimerical dream of "machine transcription" in the earlier days of ethnomusicology. Investigators using sound analysis with motion capture data have noted the contrast between their findings and those of others based on performance experience (Haugen 2015). With those lessons learned in mind, however, the Norwegian Centre for Folkmusic and Folkdance research team is augmenting the technical data, "softening" it by eliciting concomitant experiential reports from the participants (Mæland and Viken 2015). These technologies remain tools with which we may well peer more closely into the shared production of music and dance performance. While perhaps offering more finer-grained analyses and more precise explanations of such interactions, they will not provide meaningful interpretation of these phenomena. How the myriad possibilities of choreomusical expression are used, how they signify, the experiences they constitute, and ways of being-in-the-world that they call forth, will remain phenomenological-hermeneutic questions within the existing disciplines of ethnomusicology and ethnochoreology.

\section{Conclusion}

The term choreomusical is not all that new or surprising a neologism, which usefully identifies a broad area of investigation at the heart of which is a conviction that music and dance, to put it simply, or humanly structured sound and movement performance, to use one of many possible more general and less culture-specific characterizations, is very often a jointly produced performance that will reward its holistic analysis and interpretation. This challenges a significant perspective in musicology and, more especially, in dance studies (choreology) which always struggles to assert its equality with music, often by asserting that dance and music are two independent and self-sufficient systems of expressive communication that can be studied separately (Giurchescu - Torp 1995: 144). There can be no argument that either music or dance as 
cultural performance is always culture specific in conception and only theoretically segregated from other modes of expression with which they also often appear together: visual, customary, or material and so on. But music and dance, understood as performance through sounding and moving when they occur in tandem, have a particularly close and special relationship. Both give form to their ineffable materials through the rhythmic structuring of temporal experience. Thus, while choreomusicology may well be an apt name for a field of study that encompasses the many levels at which music and dance come together and interact (in sound and movement, in cultural conception and institutionalization, in the persons of dancer and musician) and the modifier choreomusical may be used to name this entire set of phenomena, I prefer to anchor this concept to that profound place of mutual generation from whence much of the joint affective power of music and dance emanates.

\section{November 2016}

\section{References}

András, Jánosi. 2009. A Magyar Népzene Előadásmódja. Gyurcsó István Alapítvány Könyvek 45, Dunaszerdalhely: Csemadok Művelődési Intézete.

Ballantyne, Patricia H. 2012. Why can't you dance to the piper? In: Russell, Ian - Goertzen, Chris (eds.): Routes and Roots: Fiddle and Dance Studies from around the North Atlantic 4. Aberdeen: The Elphinstone Institute: 176-189.

Barz, Greg - Cooley, Timothy J. (eds.). 1997. Shadows in the Field. Oxford: Oxford University Press.

Blom, Jan Petter. 1981. The Dancing Fiddle: On the Expression of Rhythm in hardingfele slåtter I: Norsk folkemusikk. Serie 1, Hardingfeleslåttar. Band 7, springar i 3/4 takt = Norwegian folk music. Series 1, Slåttar for the harding fiddle. Volume 7, springar in 3/4 time. Red. Blom, J. P. - Nyhus, S. - Sevåg, R., Oslo Universitetsforlaget Antall pensumsider: 8: 305-312. [201612-01] Retrieved from: http://www. hf.uio.no/imv/english/research/ projects/fiddlevolumes/thehardi/ volume7/dancing/index.html.

Blom, Jan Petter. 2006. Making the Music Dance: Dance Connotations in Norwegian Fiddling. In: Russell, Ian
- Alburger, Mary Anne (eds.): Play it Like It Is: Fiddle and dance studies from around the North Atlantic. Aberdeen: Elphinstone Institute: 75-86. Cooke, Peter. 1986. The Fiddle Tradition of the Shetland Isles. Cambridge: Cambridge University Press.

Cranitch, Matt. 2008. The rhythmic dimension in fiddle-playing as the music moves to newer performing and learning contexts. In: Russell, Ian - Alburger, Mary Anne (eds.): Driving the Bow: fiddle and dance studies from around the North Atlantic 2. Aberdeen: Elphinstone Institute: 121-123.

Dąbrowska, Grażyna - Petermann, Kuret (eds.). 1983. Analyse und Klassifikation von Volkstänzen. Krakow: PWM.

Damsholt, Inger. 1999. Choreomusicological Discourse: The Relationship between Dance and Music. PhD dissertation, University of Copenhagen.

Dick, Christopher S. 2016. Digital movement: computer aided analysis of human motion the case of tango. [201611-21] Retrieved from: http://www. dancetangomusic.com/pub/DickDigital-Movement-2016-Poster.pdf. 
Doherty, Liz. 2015. The Cape Breton

Fiddle Companion. Sydney, NS:

Cape Breton University Press.

Eriksson, Karen - Nilsson, Mats.

2010. Ethnomusichoreology?

Ethnochoreomusic? In: Russell, Ian -

Kearney Guigne, Anna (eds.): Crossing

Over: Fiddle and dance studies from

around the North Atlantic 3. Aberdeen:

Elphinstone Institute: 260-264.

Feld, Steven - Keil, Charles (eds.). 1994.

Music Grooves: Essays and Dialogues.

Chicago: Chicago University Press.

Felföldi, László. 2001. Connections between

Dance and Dance Music: Summary

of Hungarian Research. Yearbook

for Traditional Music 33: 159-165.

Foley, Catherine E. 2008. An Exploration of Percussive Dance at Trath na Gcos, 2002. In: Maloney, Mick - Morrison, J'aime - Quigley, Colin (eds.): Close to the Floor: Irish Dance from the Boreen to Broadway. Madison: University of Wisconsin, Macater Press: 47-56.

Giurchescu, Anca - Torp, Lisbet. 1995.

Dance - Music Relationships: An Introduction. In: Dabrowska, Grazyna Bielawski, Ludwik (eds.): Dance Ritual and Music. Proceedings of the 18th Symposium of the Study Group on Ethnochoreology, The International Council for Traditional Music, August 9-18, 1994 in Skierniewice, Poland. Warsaw: Polish Society for Ethnochoreology, Institute of Art, Polish Academy of Sciences: 143-150.

Hahn, Tomie. 2007. Sensational Knowledge: Embodying Culture through Japanese Dance. Middletown: Wesleyan University Press.

Haugan, Mari Romarheim. 2015.

Assymetrical Meter in Scandinavian Folk Music and Dance: A Case Study of Norwegian Telespringar. In: Ginsborg, J. Lamont - Phillips, A. - Bramley, M. (eds.): Proceedings of the Ninth Triennial Conference of the European Society for the Cognitive Sciences of Music, 17-22 August 2015, Manchester, U. K.: n. p. [2016-12-01] Retrieved from: https://www.academia.edu/15162184/ Asymmetrical_meter_in_Scandinavian_
folk_music_and_dance_A_case study_of_Norwegian_Telespringar.

Herdman, Jessica. 2010. 'Old Style' Cape Breton Fiddling: narrative, interstices, dancing. In: Russell, Ian - Kearney Guigne, Anna (eds.): Crossing Over: Fiddle and dance studies from around the North Atlantic 3. Aberdeen: Elphinstone Institute: 156-175. Hoerburger, Felix. 1956. Die Zwiefachen. Gestaltung und Umgestaltung der Tanzmelodien im nördlichen Altbayer. Akademie Verlag. Berlin.

Hoerburger, Felix. 1960. On relationships between music and movement in folk dancing. Journal of the International Folk Music Council 12: 70.

Hodgins, Paul. 1992. Relationships between score and choreography in twentieth-century dance: Music, movement, and metaphor. Lewiston (NY): Edwin Mellen Press.

Johnson, Sherry. 2010. Step dancing to hip hop? Reconsidering the interrelationship between music and dance in the Ottawa Valley step dancing community. In: Russell, Ian Kearney Guigne, Anna (eds.): Crossing Over: Fiddle and dance studies from around the North Atlantic 3. Aberdeen: Elphinstone Institute: 148-155.

Jordan, Stephanie. 2011. Choreomusical conversations: Facing a double challenge. Collected Work: Dance research journal. XLIII/1 (Summer 2011): The choreographic identity in question. Published by: Champaign, IL, United States: University of Illinois Press. (AN: 2011-02353). 43: 1: 43-64.

Katzarova, Raina. 1960. Le manque de coincidences entre la figure choreographique et la phrase melodique. Journal of the International Folk Music Council 12: 68.

Keali'inohomoku, Joann Wheeler. 1965. Dance and Self-Accompaniment. Ethnomusicology 9: 3 (Sep.): 292-295.

Keali'inohomoku, Joann Wheeler. 1974. 'Dance is Music in Four Dimensions' presented at the Joint Conference of CORD and SEM, San Francisco. 
Keali'inohomoku, Joann Wheeler. 1995. The conviction of Gertrude Prokosch Kurath about the interconnections of dance and music. UCLA Journal of Dance Ethnology 19: 1-5.

Kurath, Gertrude. 1957. DanceMusic interdependence. Ethnomusicology 1: 10: 8-11.

Mæland, Siri. 2015. Danse ein melodi. Veit me alt, eller kan rørsledeteksjon og elicitationintervju vera verktøy til å utforska dette nærare? Folkdansforskning i Norden [Nordic Dance Research] 38: 10-13.

Mæland, Siri - Viken, Sjur. 2015. „Dancing a Tune" in Panel: Soft and hard Broadening dance agency by combining elicitation and motion capture. Cut \& Paste: Dance Advocacy in the Age of Austerity, felleskonferanse for Society of Dance History Scholars og Congress on Research in Dance, Aten, June 4-7.

Martin, Gyorgy. 1964. Szempontok a neptainc es nepi tanczene kapcsolatainak vizsgalatahoz (vazlat). (Aspects of the Analysis of Folk Dance and Dance Music Relationship.) Tancmuveszeti Ertesito 1964: 1: 88-92. Mason, Paul H. 2012. Music, dance, and the total art work: Choreomusicology in theory and practice. Research in dance education 13: 1: 5-24.

Melin, Mats. 2015. One with the music: Cape Breton Step Dance tradition and transmission. Sydney, Nova Scotia: Cape Breton University press.

Mohd Anis Md Nor - Stepputat, Kendra (eds.). 2016. Sounding the Dance, Moving the Music: Choreomusicological Perspectives on Maritime Southeast Asian Performing Arts. Milton Park and New York: Routledge.

Nilsson, Mats. 1995. Let's Meet in the Beat. In: Dabrowska, Grazyna - Bielawski, Ludwik (eds.): Dance Ritual and Music. Proceedings of the 18th Symposium of the Study Group on Ethnochoreology, International Council for Traditional Music August 9-18, 1994 in Skiernierwice, Poland. Warsaw: Polish Society for
Ethnochoreology, institute of Art Polish Academy of Sciences: 211-215. Quigley, Colin. 1985. Close to the Floor: Folk Dance in Newfoundland. Folklore and Language Publications Monograph Series No. 3. St. John's: Memorial University of Newfoundland.

Quigley, Colin. 1995. Music from the Heart: Compositions of a Folk Fiddler. Atlanta: University of Georgia Press. Quigley, Colin. 2006. Keynote Address. ‘Dancing Bows and Musical Feet. North Atlantic Fiddle Convention'. Aberdeen, Scotland. 29 July 2006.

Quigley, Colin - Maloney, Mick - Morrison, J'aime (eds.). 2008a. Close to the Floor: Irish Dance from the Boreen to Broadway. Madison WI: University of Wisconsin, Macater Press.

Quigley, Colin. 2008b. Nationalism and Scholarship in Transylvanian Ethnochoreology. In: Shay, Anthony (ed.): Balkan Dance. Jefferson, NC and London: McFarland \& Company: 116-129. Quigley, Colin. 2008c. Step Dance in Canada: From Shared Vernacular to Regional Styles. In: Quigley, Colin - Maloney, Mick - Morrison, J'aime (eds.): Close to the Floor: Irish Dance from the Boreen to Broadway. Madison WI: University of Wisconsin, Macater Press: 35-46.

Rakočević, Selena. 2007. A Comparative Analysis of Musical and Dance Structures: The Case of Banatian Veliko Kolo. In: Golemovic, Dimitrije (ed.): Research on Dance and Music in the Balkans, International Symposium, Brcko, Decembre 0609, 2007. Papers. Brcko: Association for Fostering of the Serb CulturalHistorical Heritage Bastinar: 164-181. Rhodes, Willard. 1956. On the Subject of Ethno-musicology. Ethnomusicology Newsletter 7: 1-9. Rice, Timothy. 1995. The Dialectic of Music and Dance in Bulgaria. In: Dabrowska, Grazyna - Bielawski, Ludwik (eds.): Dance Ritual and Music, Proceedings of the 18th Symposium of the Study Group on Ethnochoreology, The International Council for Traditional 
Music, August 9-18, 1994 in Skierniewice, Poland. Warsaw: Polish Society for Ethnochoreology, Institute of Art, Polish Academy of Sciences: 217-228. Shoupe, Catherine A. 2006. The fiddle and the dance in Fife: The legacy of 'Fiddley' Adamson, father and son. In: Russell, Ian - Alburger, Mary Anne (eds.): Play it like it is: fiddle and dance studies from around the North Atlantic. Aberdeen: The Elphinstone institute: 42-49. Shoupe, Catherine A. 2008. The 'problem' with Scottish dance music: Two paradigms. In: Russell, Ian - Alburger, Mary Anne (eds.): Driving the Bow: fiddle and dance studies from around the North Atlantic 2. Aberdeen: Elphinstone institute: 105-120.

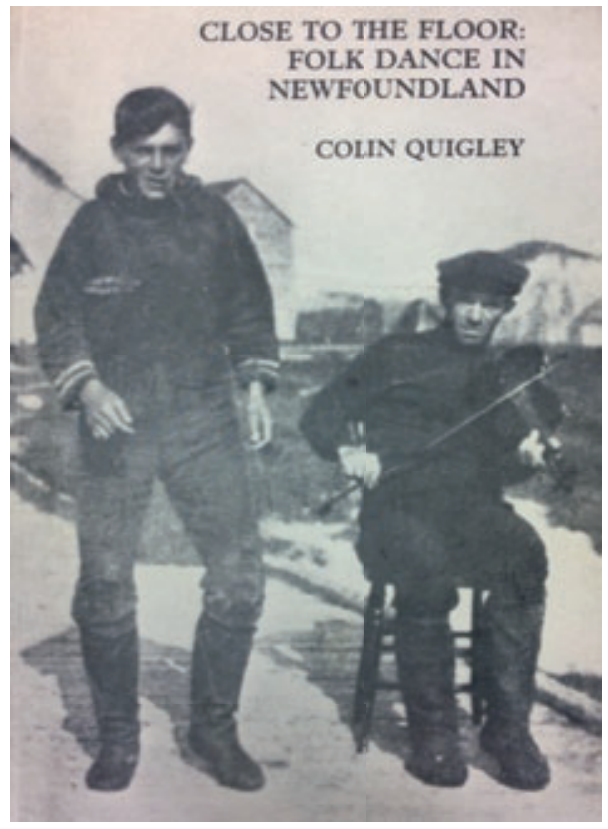

Cover image of step dancer Ralph Coles and Will White, fiddler, Sandy Cove, St. Barbe district, Great Northern Pennisula, 1929, from Quigley 1985; original from Elisabeth B. Greenleaf and Grace Y. Mansfield, Ballads and Sea Songs of Newfoundland, Harvard University Press 1933, copyright $\odot 1933$ by the President and Fellows of Harvard College, 1961 @ by Elisabeth B. Greenfield and Grace Y. Mansfield.
Sparling, Heather. 2005. 'Song

Genres, Cultural Capital and Social Distinctions in Cape Gaelic Breton' (unpublished doctoral dissertation, York University, Canada): 291.

Thompson, Gordon R. - Yodh, Medha. 1985.

Garba and the Gujaratis of Southern

California. Asian music in North America.

Selected reports in ethnomusicology. No. 6, Los Angeles, CA: University of California (Department of Ethnomusicology and Systematic Musicology): 59-82.

Virágvolgyi, Márta - Felföldi, László. 2000. A széki hangszeres népzene. Budapest: Planétás Kiadó.

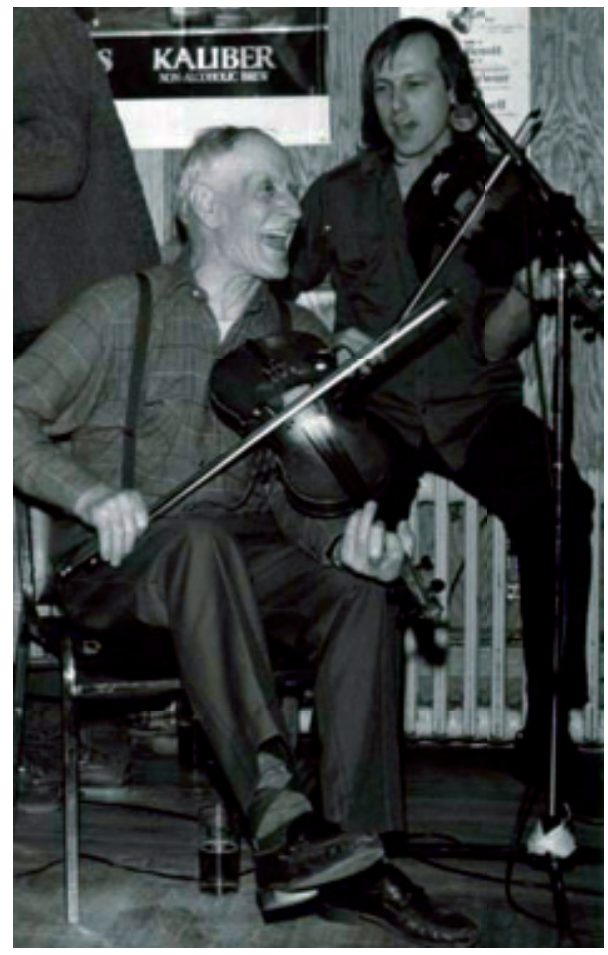

Emile Benoit performing with Kelly Russell (courtesy Kelly Russell). 


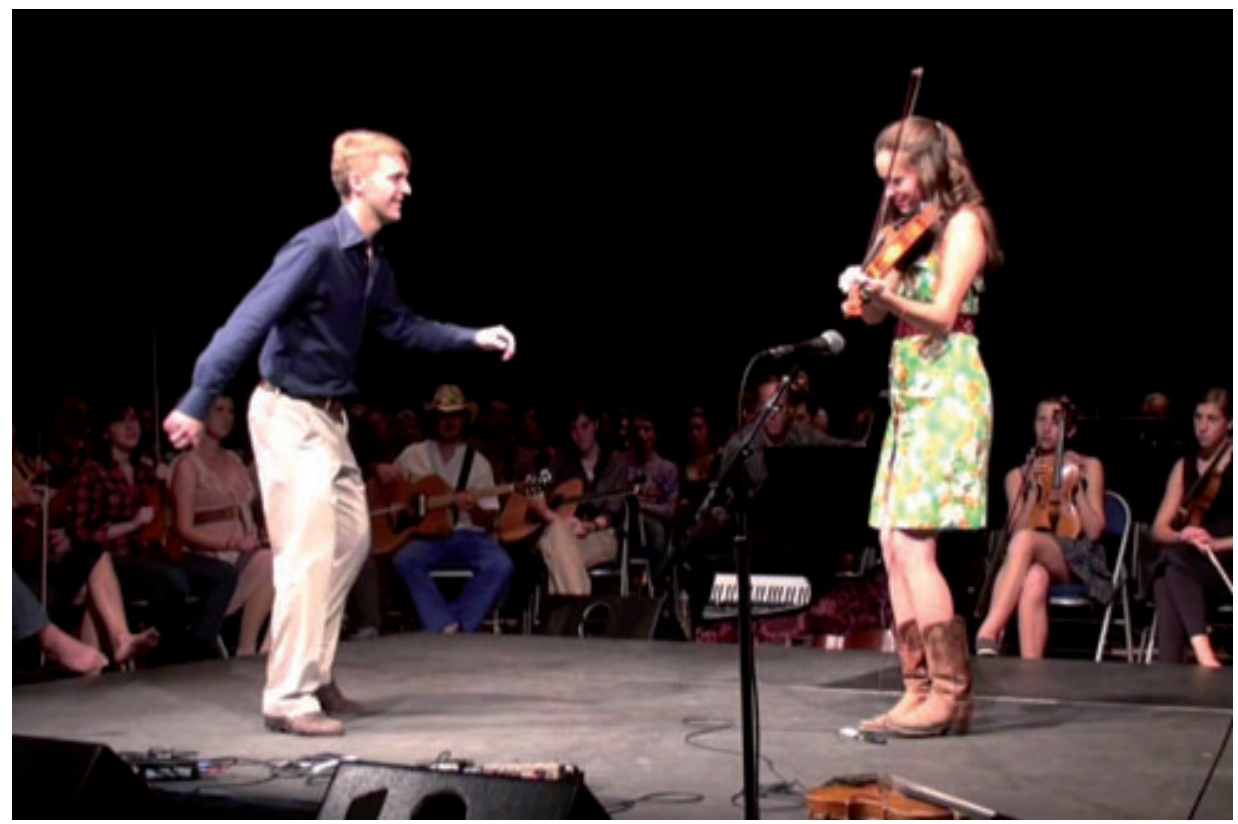

Dancer Nic Gareiss and old-time Appalachian fiddler Britany Haas, from https://www.youtube.com/watch?v=KUcaPcIkKus (photograph by Amy Luper)

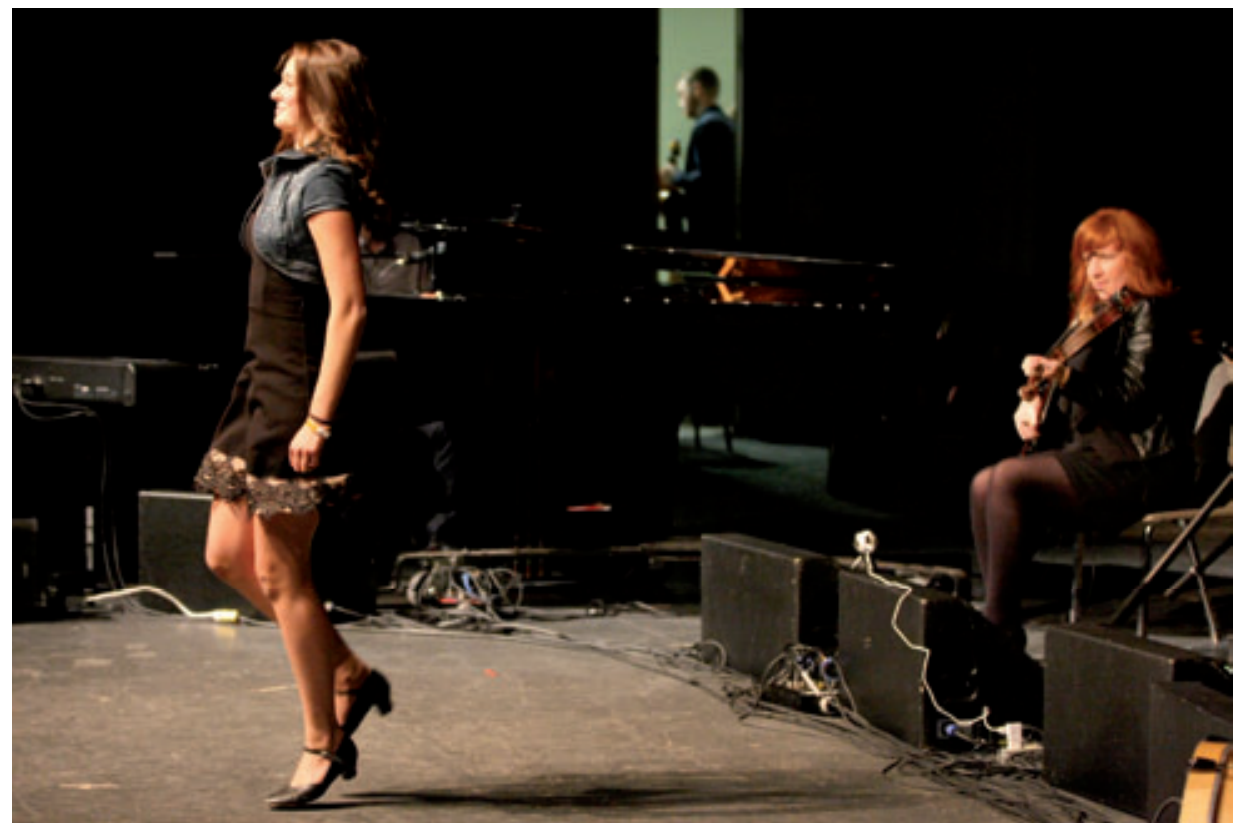

Amanda MacDonald step dancing with Mairi Rankin on fiddle. Close to the Floor concert Celtic Colours, Oct 2016 (courtesy David Greenwell). 


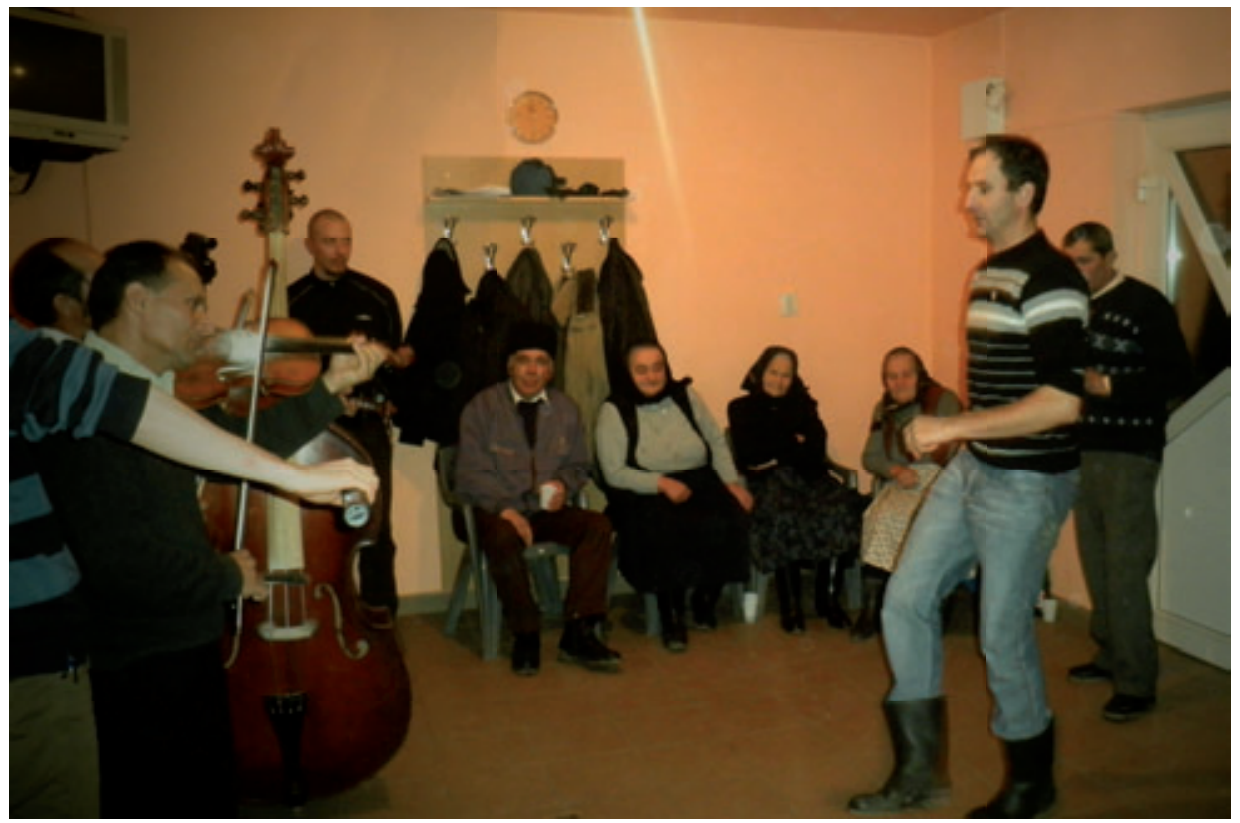

Juhos Attila (1976) dances târnaveană to the playing of Matingo Ignat "Kicsi Náci" (violin) in the village of Palatka (Palatca), Romania (photograph courtesy of Sándor Varga).

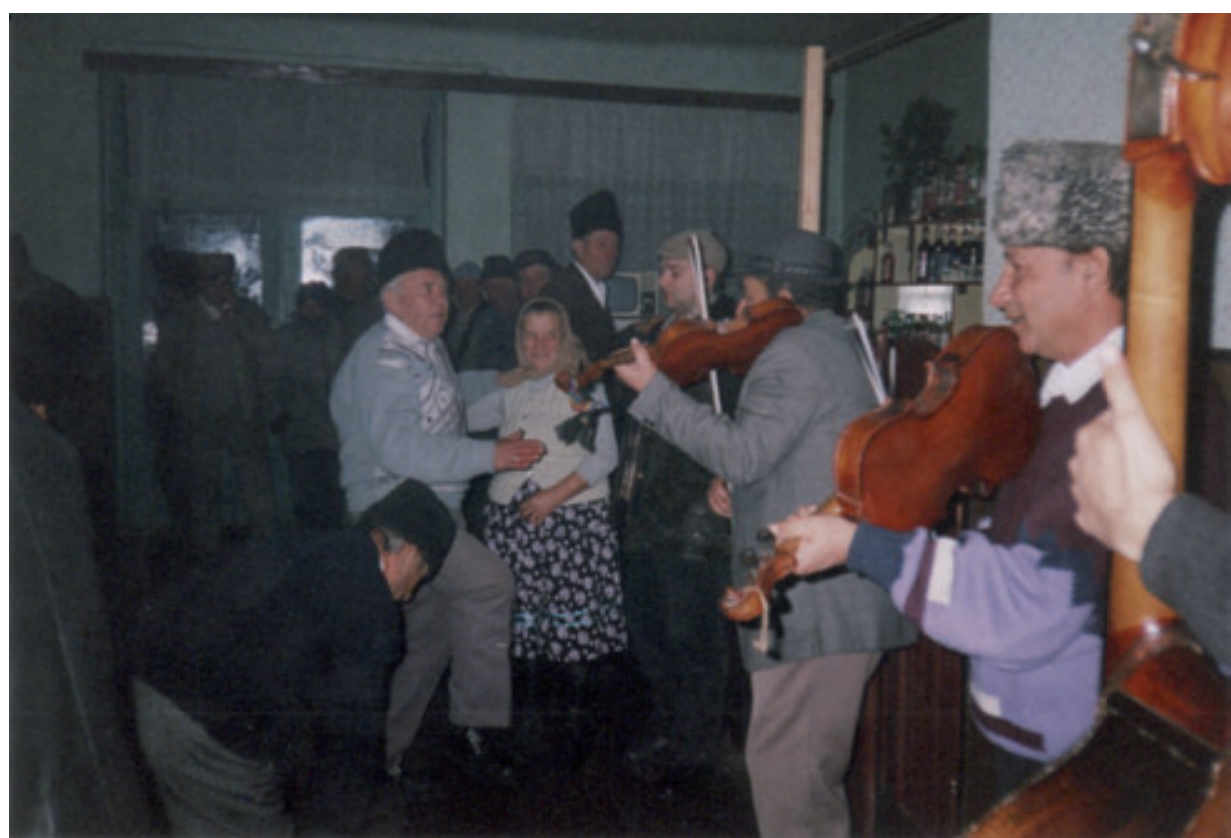

The band from Palatka (Palatca) village, Romania, led by violinist Martin Kodoba (1941-2003) play for Mihály Fodor "Mihálykó Misi" (1938) and his cousin Margit (Fodor) Papp "Mercuk" (1941) dancing the couple dance, szökős (batuta rara) (photograph courtesy of Sándor Varga) 


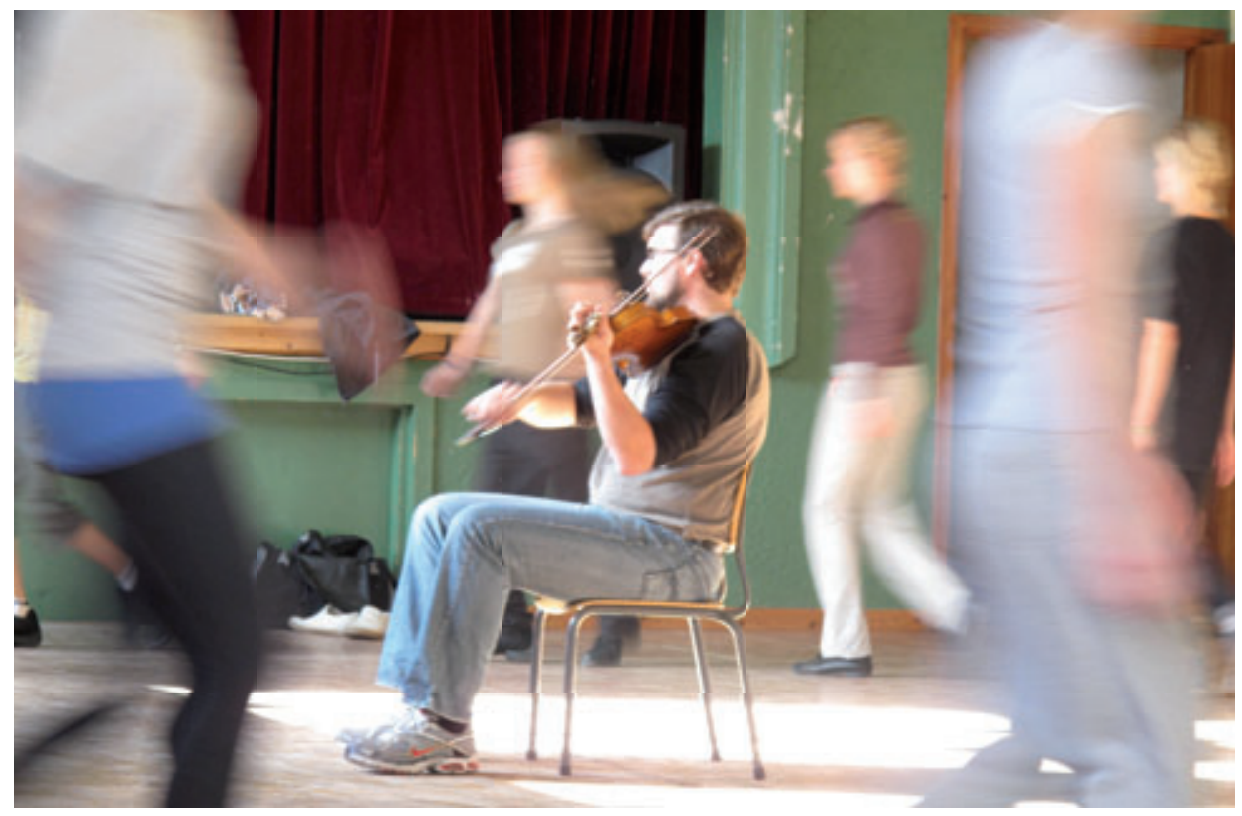

Jan Beitohaugen Granli, playing fiddle for young dancers at Bygda Dansar workshop in Sjåk village in the region Oppland, Norway (September 2009) (courtesy of the Norwegian Centre for Folkmusic and Folkdance).

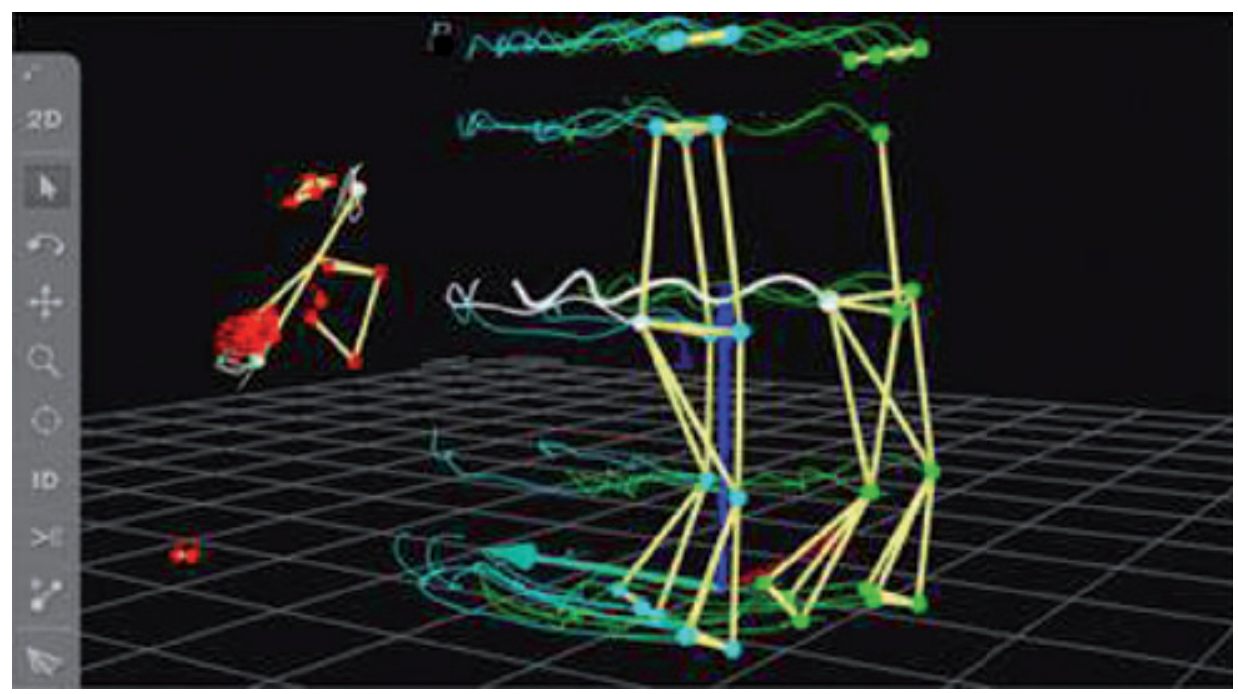

Screenshot from a motion capture 3D video-recording of a fiddle player and two dancers detected simultaneously to analyze music dance relationships. They are performing Springleik, a Norwegian traditional dance/tune. The dots show black cursor (reflective spheres) placed on their joints. Lines are drawn up manually by the researchers to capture a more holistic image. The waves behind the persons are generated by the computer and display the vertical movements made in advance of the exact moment at play. 